\title{
DIE GETUIENIS VAN DIE EVANGELIE VOLGENS MATTHEUS OOR DIE MAAG- DELIKE GEBOORTE VAN JESUS CHRISTUS
}

\author{
DR. P. J. THEO KOEKEMOER
}

\section{INLEIDENDE OPMERKING:}

Wanneer mens in verband met die kerklike leer van die maagdelike geboorte van Jesus Christus, die filologiese betekenis van 'almâ en betulâ in die Ou Testament nagaan, asook die betekenis van parthenos en neanis in die LXX en verder ' $n$ eksegese van Jes. 7:14 en Miga 5:1-4, is die volgende sake baie duidelik:

(a) Die Hebreeuse 'almâ beteken nie maagd nie, maar wel 'n jong getroude vrou totdat sy haar eersgeborene gebaar het; kan ook 'n hubare meisie beteken by wie die maagdskap wel ver. onderstel mag word, maar nie noodwendig soos by die betulâ (maagd „virgin") nie.

(b) Die vraag waarom die LXX vertalers 'almâ met parthenos vertaal het, is moeilik finaal te beantwoord, maar is waarskynlik te verklaar uit die ",behoefte" om die wonderbare van die aangekondigde Kind en sy geboorte te onderstreep. Of hier ook sprake is van 'n ,nawerking" (formeel en met voorbehoud) van OudOosterste verlossersverwagting-voorstellings is 'n baie vae en verre moontlikheid.

Derhalwe: Die eksegese van die Ou Testament lewer geen onbetwisbare uitgangspunt of bevestiging vir die leer van die maagdelike geboorte van Jesus Christus nie. Die beskouing van Procksch en andere dat die 'almâ van Jes. 7:14 wel met parthenos vertaal moet word, soos die LXX dit gedoen het, is suiwer filologies nie te regverdig nie.

In hierdie artikel is die vraag na die Skrifbewys ten opsigte van al die Nieutestamentiese uitsprake aangaande die maagdelike geboorte van Jesus Christus nie nou aan die orde nie. Dis 'n vraag of daar, behalwe die gegewens van Mattheus en Lukas, enige spoor van die parthenogenesis in die Nuwe Testament is. Wat is die sin van die swye van byvoorbeeld Paulus? Ons hooftaak sien ons hier as die eksegese van die gegewens van Mattheus oor ons onderwerp, met tekskritiese voor-arbeid as teologieswetenskaplike noodsaaklikheid, terwyl die vraag van die sin van die swye in die res van die Nuwe Testament hier nie ondersoek sal word nie. 
(ii) Die gebruik van die woord parthenos ${ }^{1}$ ) in die Nuwe Testament:

Ons let op enkele vertalings van die betrokke Skrifgedeeltes: Matt. 1:23 en Matt. 25:1, 7 en 11, Luk. 1:27, Hand. 21:9, 1 Kor. 7:25, 28 en 34 en 1 Kor. 7:36 en 37, 2 Kor. 11:2, Openb. 14:4.

Die Afrikaanse-, State-, Lutherse-, Leidse- vertaling en die van prof. Brouwer, Petrus Canisius en die Ned. Bybelgenootskap ${ }^{2}$ ) vertaal parthenos in Matt. 1:23 deurgaans met maagd. Parthenos in Matt. 25:1, 7 en 11 word deur die Afrikaanse vertaling weergegee as ,,jong meisies", deur die Leidse verklaring en prof. Brouwer as „meisjes”, deur die State-, Lutherse-, N.B.G. en Petrus Canisius-vertalinge as "maagden". Ten opsigte van Luk. 1:27 merk ons op dat al die genoemde vertalinge lees "maagd" behalwe die Afrikaanse vertaling wat lees ,jongedogter". Die parthenoi (meervoud) van Hand. 21:9 word deur die Afrikaanse-, Leidse-, Brouwerse-, P. Canisiusse-, en N.B.G.-vertalinge weergegee as ,vier ongetroude (Nederl. ,ongehude”) dogters", (dochters)", terwyl die Statevertaling lees „vier dochters, ncg maagden”, en die Lutherse vertaling „vier dogters, maagde” 1 Kor. 7:25, 28, 34 word deur die Afrikaanse vertaling weergegee met ,,jongedogter(s)", so-ook deur die N.B.G.: ,,jongedochter(s)"; die Leidse vertaling vertaal vers 25 met "huwbare meisjes" en vers 28 en 34 met slegs "meisje”; die ander vier van die genoemde vertalinge lees „maagd(en)". In die eksegeties-moeilike gedeelte, I Kor. 7:36 en 37 vertaal die Afrikaanse vertaling die parthenos van vers 36 met „maagdelike dogter” en die parthenos van vers 37 slegs met „dogter". Die N.B.G. lees hier by albei tekste ,jongedochter"; so ook Petrus Canisius ,,jonge dochter"; die Lutherse vertaling lees "(wanneer zijne) dochter niet huwt . . " (vers 36 ) en ".... (zijne) dochter ongehuwd ..."

Die Leidse vertaling meen om hier te vertaal met „bruid", die State-vertaling met „maagd”. Die parthenos van 2 Kor. 11:2 vertaal die Leidse-vertaling en prof. Brouwer as „,bruid" terwyl die ander genoemde vertalinge hier lees „maagd". In Openb. 14:4 word parthenoi vertaal met maagdelik (Afrik. vert., Leidse vert., Prof. Brouwer en die N.B.G.) en "maagden" (State-, Lutherse-,

1) Vgl. Walter Bauer: Wörterbuch zum Neuen Testament, 4te Aufl., 1952; Gerhard Kittel: Theologisches Wörterbuch zum Neuen Testament; J. H. Thayer: A Greek-English Lexicon of the New Testament, Translated, revised and enlarged, 4th ed. 1930; Het Nieuwe Testament in zes Nederlandse vertalingen, 1950.

2) Vgl. „Het Nieuwe Testament in zes Nederlandse vertalingen." 
en Petrus Canisius vertalinge). Uit voorafgaande blyk dit dat die Griekse woord vir maagd, parthenos ${ }^{3}$ ) in die Nuwe Testament verskeie betekenisskakeringe het:

(a) Parthenos in die algemeen beteken gewoon ,ongetroudejongvrou." Vgl. Matt. 25:1, 7 en 11 en Hand. 21:9. Dit dui op 'n meisie, dogter of jongdogter in ongehude staat.

(b) Parthenos ten opsigte van Maria $^{4}$ ), die moeder van Jesus, vgl. Matt. 1:23 en Lukas 1:27. Maria is die jongedogter of maagd, voor die geboorte van Jesus in 'n toestand van ,völliger Unberührtheit", nog deur geen man beken nie. Die consummatio matrimonii is beslis uitgesluit. ${ }^{5}$ ). (Vgl. verder ons hiernavolgende eksegese).

(c) Parthenos in asketiese sin (?) Ten opsigte van die huwelik spreek Paulus onder andere in 1 Kor. 7. Ons latere, hierna volgende eksegese sal probeer uitmaak of die betekenis van parthenos in 1 Kor. $7: 25,28,34,36$ en 37 'n asketiese lewensvorm openbaar, al dan nie.

(d) Parthenos in afgeleide betekenis. Vgl. ons Openb. 14:4 waar parthenoi in teenstelling met „pornë" staan en dan ook in hierdie sin vertaal is deur die Afrikaanse vertaling, die Leidse vertaling, die N.B.G. en prof. Brouwer .

In 2 Kor. 11:2 word die gemeente (as die bruid van Christus) as parthenos gekwalifiseer. „Paulus hat sie durch die missionarische Gründung mit Christus verlobt und hütet sie nun eifersüchtig, um sie ihm bei seiner Parusie hochzeitlich zuzuführen"').

Bogemelde gedeeltes $a, b, c$ en $d$ vra om nadere eksegetiese toeligting. Uit die staanspoor blyk dit egter dat nie slegs tekste met die woord parthenos ter sprake moet kom betreffende die maagdelike geboorte van Christus nie, maar byvoorbeeld ook Skrifgedeeltes waar sprake is van sy „ouers”, waar Josef en Maria sy „vader” en „moeder” genoem word, ensovoorts.

3) Gustav Delling in Kittel, Theol. Wörterb. 3 N.T. art. partenos, Bnd. 5, S. 825, wys daarop dat die etimologie van die woord onseker is en dat die semantologiese ontwikkeling ,nur aus den literarischen Belegen" vasgestel kan word. Hy wys na Herzog-Hauser en Boisacq se mening dat dit in samehang met die Griekse "then", "schwellen" (duits) en „,blühen” (duits) beteken. „Offenbar bezeichnet die Vokabel zunächst die in der Reife stehende "junge weibliche Person ...." Vgl. Hugo Koch: Adhuc virgo. Mariens Jungfrauenschaft in der altkirchlichen Ubberlieferung biz zum E. des $4 \mathrm{Jahr}$ hdts., 1929, S. 28,42 v.v. Vgl. ook Delling: a.a. O.S. 832 en 833: ,In $\mathrm{Ag} .21,9$ kann das adjectivische parthenoi die Töchter des Philippus einfach als unverheiratete bezeichnen."

4) Maria word as 'n verloofde jong meisie (Mädchen) voorgestel (Luk. 1:27) wat in haar toestand van "völliger Unberuhrtheit" (Luk. 1:27 en 34) die belofte ontvang dat sy 'n Seun sal baar uitsluitlik as gevolg van ' $n$ skeppende daad van God (Luk. 1:31 en 35), vgl. Delling: A.W. bls. 833 en Strack-Billerbeck: Kommentar zum Neuen Testament aus Talmud und Midrasch, Bnd. I. München, 1922, S. 45.

5) Strack-Billerbeck a.O. I, S. 45.

G) G. Delling: A.W. bls. 835 . 
Alhoewel gedeeltes (c) en (d) hierbo nie betrekking het op dis maagdelike geboorte van Jesus Christus nie, is dit tog heel belangrik dat ons vooraf ook hierdie betrokke Skrifgedeeltes eksegeties sal ondersoek, aangesien ons in die dogmatiese deel van hierdie studie te doen sal kry met askese as lewenshouding, as etiese vraag in die Protestantse en Roomskatolieke Etiek.

(iii) Eksegese van die belangrikste Skrifgedeeltes betreffende die maagdelike geboorte van Jesus Christus.

(1) „Jakob het Josef verwek, die man van Maria, uit wie gebore is Jesus wat genoem word Christus."

Dit is die lesing van die Sinaiticus, Vaticanus en verskeie ander mss; word ook bevestig deur Tertullianus, De Carne Christi, par. 20.

(2) „Jakob het Josef verwek aan wie verloof was die maagd Maria wat geboorte geskenk het aan Jesus wat genoem word Christus.

Hierdie is die lesing van die Ferrargroep en word ook bevestig deur verskeie vorme van die:

(3) Ou Latynse groep:

... Ioseph cui desponsata virgo Maria genuit Iesum Christum. (k).

... Ioseph cui desponsata virgo Maria peperit Christum lesum. (d).

- .. Ioseph cui desponsata virgo Maria genuit Iesum qui dicitur Christus. (a).

... Ioseph cui desponsata virgo Maria genuit lesum qui vocatur Christus. (g).

.. I Ioseph cui desponsata erat virgo Maria virgo autem Maria genuit Iesum. (b).

... Ioseph cui desponsata virgo Maria; Maria autem genuit Iesum qui dicitur Christus. (c).

(4) Die Vulgaat lees: Iacob autem genuit Joseph virum Mariae de qua natus est Iesus . . .", waarmee die syriese vertalinge ooreenkom.

(5) Die Syrus Curetonianus lui: „,Jakob het Josef verwek aan wie die maagd Maria verloof was, wie Jesus die Messias gebaar het."

(6) Die Sirus Sinaiticus lui: Jakob het Josef verwek, Josef aan wie die maagd Maria verloof was het Jesus wat genoem word Christus verwek. 
(7) Die „Dial Timoth et Aquilae”: In hierdie dialoog word Matt. 1:16 drie maal kwoteer. Hierdie derde lesing, sê Burkitt, ${ }^{7}$ ) gee 'n sprekende voorbeeld ,of how loosely and inaccurately the writer quotes the N.T." Dit lui: „Jakob het verwek Josef, die verloofde van Maria, uit wie gebore is die Christus die Seun van God."

Die tweede aanhaling lees soos volg: „Jakob (het verwek) Josef, aan wie Maria verloof was, uit wie gebore is Jesus wat genoem word Christus." Hierdie kwotasie, sê Burkitt, ,, is in a rapid recapitulation of the genealogy ... . is chiefly interesting as affording an actual proof that the phrase ",husband of Mary" was liable to change"s). Die eerste aanhaling van Matt. 1:16, gesien in die lig van die konteks, dui daarop hoe hewig die kwessie van die herkoms van Jesus tussen die christene en Jode in die diskussie moes gestaan het:

Die Christen sê: „Ja . . van Abraham is sy vlees afkomstig." Die Jood sê: „Hoe was hy gebore? Vertel aan my sy genealogie.” Die Christen sê: „U eie mond het dit verklaar toe u die Oue en Nuwe Testament gelees het, en hoe weet u dit nie?" Die Jood sê: „Daar is 'n genealogie in die Ou Testament, en in die Nuwe (Test.) is daar een in Mattheus wat soos volg lui: „Jakob het verwek Josef die man van Maria, uit wie gebore was Jesus wie genoem word Christus. En (so) het Josef Jesus, wie genoem word Christus, verwek, van wie ons praat; dit sê: hy het (hom) verwek uit Maria."9).

Twee teenoormekaarstaande tendense blyk duidelik uit bogenoemde variante lesings. Aan die eenkant sien ons 'n tendens om die maagdelikheid van Maria te beklemtoon deur uitdrukkings wat dit nie bevestig nie, te verwyder. In plaas van die kort-af lesing "Josef, haar man", lees die Cur. Syr., met die oudste latynse tekste „Josef, aan wie verloof was . . .", nie slegs „Maria” nie maar „die maagd Maria”. Die Sir. Sin. kom ooreen met sommige dele van hierdie lesings, maar toon ook die teenoorgestelde neiging met as duidelikste voorbeeld, die weergawe: „Josef het Jesus verwek." Ons kon gedink het dat dit 'n oorskrywingsfout is, as gevolg van die feit dat die telkens terugkerende egennesen van die vorige verse per ongeluk hier ingeskryf is; maar in vers 25 lees dieselfde ms. „sy het vir hom 'n seun

i) F. Crawford Burkitt: Evangelion Da-Mepharreshe . . . The Curetonian Version of the Four Gospels, with the reading of the Sinai Palimsest and the early Syriac Patristic evidence, edited, collected and arranged. Prt. 2, p. 263, 264. University Press. Cambridge 1904.

8) F. C. Burkitt: Evangelion Da-Mepharreshe. „The Curetonian Version of the four Gospels," Vol. 2, bls. 265. 1914.

9) F. C. Burkitt: Evangelion Da-Mepharreshe. "The Curetonian Version of the four Gospels." Uitg. T. en T. Clark, Edinburg, 1914. Vol. 2, bls. 265. 
gebaar”, (vgl. ook vers 21) terwyl Luk 2:5 lees „Maria, sy

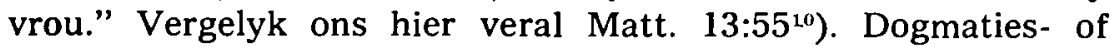
apologetiese gerigte ingryping as verweer teen die misduiding van die maagdelike geboorte is talryk. Matt. 1:3, 5, 6 bevat in sigself die verlangde apologie en verweer ${ }^{11}$ ).

Wanneer Geyser aandag skenk aan die toestand van die teks ten opsigte van Matt. 1:16 „En Jakob die vader van Josef, die man van Maria uit wie gebore is Jesus wat Christus genoem word,"

(Sien ${ }^{11}$ ) hierbo), na vergelyking met verskeie variante lesings, sê hy dat dit opvallend is dat hierdie lesing wat deur die beste manuskrip-getuienisse (o.a. die belangrike Sahidiese vertaling) bevestig word, die „onskuldige voorkoms" dra en aangesien moet word as die oorspronklike ${ }^{12}$ ).

Verdere bedoeling van die oorspronklike teks: Die Griekse egennesen, (die Hebreeuse ",holîd") beteken in eintlike sin: verwek. Jakob het Josef verwek. Hierdie betekenis word soms afgewissel in die oneintlike sin soos byvoorbeeld in vers 12 in die verhouding van Jegonja tot Salathiel as adopsie ${ }^{13}$ ).

Egennesen hoef dus nie noodwendig op 'n fisiese afkoms te dui nie, maar kan ook in legale sin opgeneem word. Josef, die man van Maria, was die legale vader van Jesus by wyse van die adopsie-praktyk van die Jode. Die skrywer was geinteresseerd in die vraag of Jesus legaal 'n afstammeling van Dawid was; indien hy die Messias is moet hy 'n Dawidied wees. Die doel van die outeur is om hier aan te toon dat Jesus die in die Ou Testament voorspelde Messias is.

10) W. Sandy: Outlines of the Life of Christ. 2de hersiene en verbeterde uitgawe. bls. 198-199, vgl. verder B. H. Streeter: The Four Gospels, 7th Ed. 1951, p. 87.

11) A. S. Geyser: Die Geslagsregister van Jesus Christus volgens Matt. 1:1-17 en Luk. 3:23-38. Pretoria 1946, bls. 157. (Sy doktorale Proefskrif).

12) A. S. Geyser: A.W. bls. 157. Vgl. hleromtrent ook: W. Sunday: Outlines of the Life of Christ, p. 197-200. Ook Eberhard Nestle: Introduction to the Textial Criticism of the Greek New Testament, 2nd rev. ed. London, 1901. p. 248-249.

13) A. S. Geyser: AlW. bis. 150 en voetnoot bis. 157. Vgl. ook F. Kenyon: Textual Criticism of the New Testament, p. 154-155: , ... . the use of the word ,begat" being precisely anologous to its use throughout the genealogy, in which as is well known, it does not always indicate literal descent, but rather an official line of succession." 
Daarom moet in die geslagsregister duidelik aangetoon word dat Jesus Christus die seun van Dawid, die seun van Abraham is $\left.{ }^{14}\right)$.

Klaarblyklik is die geslagsregister en die daarmee verbonde verhaal van die maagdelike geboorte, wat voorasnog mondeling in omloop was, juis in die evangelies volgens die beskrywing van Mattheus en Lukas opgeneem, asgevolg van die Joodse laster oor die herkoms van Jesus ${ }^{15}$ ). Aangesien hierdie lasterverhale reeds alom bekend was teen die begin van die tweede eeu, kan die ontstaan daarvan veel vroeër gestel word, ,tot die tyd voor die skriftelike optekening van die evangelies volgens Mattheus en Lukas"'w).

Die maagdelike geboorte was dus eerste en daarna is dit geamendeer! Die lasterstories kon alleen ontstaan het teen die feit dat die verhaal van sy maagdelike geboorte reeds in omloop was. Teen hierdie vyandelike Joodse lastergees ten opsigte van wonderbaarlike herkoms van Jesus moes die eerste Christene iets doen. In die omstellinge en aanvullinge van die tekste van veral Matt. 1:16 (en Luk. 3:23) klink die apologetiese tendens deur. In die ooglopend is dat die mate waarin Jes. 7:14 (LXX) die neiging toon om Maria as maagd voor te stel en so in die persoon van Jesus die profesie te vervul, by Mattheus sterk

14) A. S. Geyser: A.W., bls. 3 v.v. verwys na die lasterstories. In die rabbynse literatuur word Jesus genealogies geplaas as "Jeschua ben Pantera." Jesus is die seun van die Romeinse soldaat Panther. Celsus het geleer: "... sy geboorte uit 'n maagd is 'n versinsel; hy is gebore in 'n sekere Joodse dorpie uit 'n arm vrou van die platteland wat in haar onderhoud voorsien het deur te spin. Sy is deur haar eggenoot, 'n timmerman. die huis uitgesit omdat sy skuldig bevind is aan oorspel; nadat sy geruime tyd rondgeswerf het. het sy geboorte gegee aan die buite-egtelike kind Jesus. (Orig. contra Celsum I, 28). Wat Irenaeus (Adv. Haer III, 21, 1: V. 1. 3; V, 19, 2) vertel oor die houding van die Ebioniete ten opsigte van die maagdelike geboorte, word bevestig deur Justinus in sy dispuut met die Jood Trypho. (Just. Dial. cum Trypho 48). Dat Jesus seun van Dawid is, blyk 'n tipiese kenmerk van Mattheus se opvatting te wees: 9:27, 12:23. 15:22. 21:9 en 15, 19:28. 25:34.

15) Vgl. hieroor A. S. Geyser: A.W. bls. 3 v.v. wie daarop wys dat (op sy beurt) hierdie teboekstelling weer Joodse reaksie verwek het - die waarvan Celsus spreek en waaroor ons verdere mededeling het in die "Toldoth Jeschu."

1F) Vgl. A. S. Geyser: A.W. bls. 7 en 8 ,Teen die begin van die tweede eeu n.C. was die Joodse verhaal in verband met die illegitieme herkoms van Jesus dus al wyd bekend ... Die substratum waarop dit gegroei het, was die (toe nog mondelinge) genealogiese gegewens oor die herkoms van Jesus en sy geboorte uit die maagd." (ons onderstreep). Behalwe die laster van Celsus se "Logos alethềs" is ook nog te noem die van Rabbi Eliëser die Grote, die Toldoth Jeschu wat eers veel later tot stand gekom het, die "Samaritaanse Kroniek", die Ebionitiese stories in navolging van Theodoton die Efesiër, (c. 180 n.C.) en Aquila van Pontus (c. 129 n.C.). Vgl. hieroor A. S. Geyser, A.W. bls. 2.10. 
nagewerk het. Geeneen van die evangeliste hou soveel daarvan as hy om telkens te sê: "Sodat vervul sou word die woord wat gespreek is deur die profeet . . " Vgl. Matt. 1:23; 2:5, 15, 17, 23; 3:3.

Matt. 1:18 v.v.: Die geboorte van Jesus Christus. Vers 18: „Die gebooorte van Jesus Christus was dan so: Toe sy moeder Maria verloof was aan Josef, voordat hulle saamgekom het, is sy swanger bevind uit die Heilige Gees."

By die syr. sin. en syr. cur. asook by Irenaeus ontbreek "Iesou"17). Van Leeuwen vertaal dan ook 18a soos volg: „Met de geboorte van den Christus was het zóó gelegen:" ${ }^{18}$ ), en voeg hy verklarend daaraan toe: „Zoo toch meenen wij te moeten lezen, op grond van de oudste vertalingen en van het belangrijke getuigenis van sommige kerkvaders" ${ }^{10}$ ). In elk geval verskil minstens ses Nederlandse Bybelvertalings met Van Leeuwen, te wete die State-, Lutherse-, Leidse-, N.B.G.-vertalinge, asook die vertalings van prof. Brouwer en Petrus Canisius.

Verskeie manuskripte lees gennesis in plaas van genesis. Origens ken ook slegs gennesis Westcott en Hort erken laasgenoemde in hulle aanhangsel. Weiss sien dit as 'n verandering wat gemaak is in ooreenkoms met die verbale vorme egennēse en egennēthe in die vorige deel van die hoofstuk; laasgenoemde word hierin ondersteun deur $\mathbf{Z a h n}^{20}$ ) Op hierdie verskil hoef ons verder nie te let nie aangesien die verskil tussen gennēsis en genēsis geen wesensverandering in die betekenis van die teks ten opsigte van die maagdelike geboorte aanbring nie. In die N.T. Grieks ${ }^{21}$ ) beteken genēsis in die eerste plek bron (source), oorsprong (origin) en in die tweede plek geboorte (birth, nativity) terwyl gennēsis beteken verwekking (begetting) of voortbrenging (engendering), maar kan ook geboorte beteken, soos genesis.

Wel van belang vir 'n studie van die maagdelike geboorte van Jesus Christus, is die siriese ,kommentaar" of aanhaling van Barsalibi ten opsigte van Matt. 1:18.

1i) E. Nestle: Introduction to the Text. Crit. of the Greek N.T., bls. 250.

18) J. A. C. van Leeuwen: Het Evangelie van Mattheus, in die serie T. en U. 2de druk, Groningen 1918, bls. 21.

19) Dr. J. A. C. van Leeuwen: Het Evangelie van Mattheus, bls. 70.

20) E. Nestle: A. W. bls. 250.

21) J. H. Thayer: A Greek-English Lexicon of the New Testament, bls. $112,113$. 
F. C. Burkitt ${ }^{22}$ ) gee die vertaling uit Siries in Engels soos volg: „Here the manner of His corporeal birth (the Evangelist) teaches. When therefore thou hearest the word ,husband" do not suppose that $\mathrm{He}$ is to be born by the Law of Nature, who Himself prescribes the Law of Nature. And when it comes to Joseph it says "Who begot the Messiah", and for that reason afterwards it says "The birth of Jesus the Messiah was thus", i.e. "not as the rest of mankind was He born, but a new thing is the manner of his birth."

\section{Wat wil Matt. 1:18 eintlik meedeel?}

By nadere ondersoek blyk dit dat die terminologie hier gelade is, ' $n$ bepaalde agtergrond het. Ons het in die eerste afdeling van hierdie studie, handelende oor die Ou Testamentiese aspekte, prof. Miskotte, toegestem dat die eksegeet steeds die "Israelitiese karakter" van die Nuwe Testament in die oog moet hou.

Doen mens dit nie, bestaan die gevaar dat die geladenheid of agtergrond van bepaalde woorde of uitdrukkings in die vertaling nie sal meespreek nie, dat die vertaling derhalwe minder duidelik of selfs foutief kan wees, soos ons straks sal aantoon in die geval van die Afrikaanse vertaling van hierdie vers (1:18). „Die waarde en betekeniskleur wat ons aan bepaalde woorde en gedagtes heg," byvoorbeeld aan die woord „verlowing", ,huwelik", "maagd" ens. is waarskynlik iets anders as diê van die Jode of Grieke. Daarom het die Nuwe Testamentiese wêreld met die woord verlowing (1:18) waarskynlik ook hier iets anders in die oog as ons westerlinge. Hierdie feit dat 'n woord ingebed is in sy tydsagtergrond, is van beslissende belang vir die eksegese $\left.^{23}\right)$.

Matt. 1:18 wil meedeel dat Maria as maagd swanger bevind is nog tydens die verlowing en wel voordat hulle "saamgekom" het; dat hierdie swangerskap geskied het uit die Heilige Gees en nie deur Josef nie.

22) Wat die oorsprong is van hierdie lesing, laat Burkitt in die midde . . ,Whe!her this be Barsalibi's own comment on the Peshitta text, or a quotation from some ancient writer who had before him a text like that of $S$. it is after all a sound exposition of the general meaning of the passage Matt. 1:16 ff.. a question which should be kept quite distinct from the criticism of the general Christian tradition as to the Nativity. Vgl. C. F. Burkitt: Evangelion Da-Mepharreshe, deel 2, bls. 266.

23) Vgl. Prof. dr. B. I. Engelbrecht: Art. in Herv. Theol. Studies, 7de jrg. Afl. IV, Mei 1951, bls. 192. 'n Ander sprekende voorbeeld van wat ons bedoel, vind ons by prof. dr. A. van Selms: Art. „Die Stad in die Israelitiese Voorstellingslewe." Herv. Theol. Studies. 8, 11 bls. 79v. 
Die Joodse verlowing kiddûsin ('arusinn) is deur die Joodse wet in baie ernstige lig gesien ${ }^{2 t}$ ).

Dit blyk onder andere hieruit dat die verloofde meisie volgens die reg reeds genoem word die „bruid" 'arasâ en die „vrou” 'išsâ van die man aan wie sy verloof is. Sy kan selfs, terwyl sy verloof is, 'n „weduwee" of "geskeide vrou" genoem word indien haar verloofde man sterf of haar 'n skeibrief gee; sy het selfs dan die reg om haar ketuba, 'n deel van die bruidskat op te eis ${ }^{25}$ ). In Galilea, die tuiste van Josef en Maria, was die verloofde meisie wettig die vrou van haar man, maar hulle kon nog nie „saamkom" sunetthein nie, ,weil das Alleinsein der Brautleute dort (in Galilea) überhaupt nicht üblich war . . " ${ }^{26}$ ). Ons moet hierdie sunelthein teen sy Joodse agtergrond tans nader in die oog kry. Die Afrikaanse Bybelvertaling lui: „... . voordat hulle saamgekom het ..." Die Statevertaling en in navolging daarvan die Afrikaanse vertaling het sunelthein na sy woordelike betekenis gaan vertaal, waarskynlik met die veronderstelling dat ons hier te doen het met 'n eufemistiese uitdrukking vir die egtelike gemeenskap in geslagtelike sin . . ,voordat hulle saamgekom het."

Maar sunelthein beteken in idiomatiese Grieks, „om saam te woon" wat werklik ook die inhoud van die gedagtegang is, presies volgens die Joodse huweliksgebruik. Teenoor die ondertrouing, beteken die saamwoning gewoonweg die huwelik. Die teks wil dus meedeel: terwyl Maria en Josef nog verloof was en voordat hulle getroud is, het sy swanger geword, ,,voordat hulle saam gaan woon het." Hierdie vertaling word ook gegee deur die jongste vertaling van die Nederlandsch Bijbelgenootschap; ,voordat zij gingen samenwonen":-). Alhoewel Calvyn die sunelthein ook betrek op die geslagtelike gemeenskap ${ }^{28}$ ), erken hy dat dit ook kan beteken ,voordat hulle saamgekom het

24) W. C. Allan: St. Matthew. I. C. C. Edinburgh, 1947, P. 9. „Bethrothal according to Jewish marriage law constituted a legal relationship which could only be dissolved by legal means."

25) Strack-Billerbeck: a.a. O. vol. 2. S. 393-394. Vgl. hieromtrent ook: N. Levison: The Jewish Background of Christianity", 1932, p. 129. "The engagement was looked upon almost the same as marriage. and the breaking-off of an engagement had to go through a legal process similar to that of divorce."

26) Stack-Billerbeck: a.a. O. vol. 1. S. 45.

27) Vgl. hieroor A. S. Geyser: Art. in Hervormde Teol. Studies, 6de Jrg. 1949-1950, bls. 35. Vgl. ook die vertaling van prof. Brouwer: „... eer zij waren gaan samenwonen ... ." en Petrus Canisius: „... voordat ze gingen samenwonen ..."

28) Commentary on a Harmony of the Evangelists, Matthew, Mark, and Luke, by John Calvin, translated by the Rev. W. Pringle. Vol. I, p. 93-94, Grand Rapids, 1949. So ook A. Schlatter: Der Evangelist Matthäus: 2 Aufl. Stuttgart. 1933, S. 12. 
as man en vrou om 'n huis en familie te stig", dat die maagd nog nie deur haar ouers in die hande van die bruidegom gegee is nie, maar nog steeds onder hulle dak verkeer het.

Aangesien die verlowingstydperk van die na'arâ gewoonlik ietwat langer as twaalf maande geduur het, het die huwelik op die ouderdom tussen dertien en 'n half en veertien jaar plaasgevind. (Vir die meisie was die normale verlowingstyd terwyl sy nog na'arâ was, dit wil sê tussen twaalf en twaalf en 'n half jaar $)^{29}$.

Hierdie swangerwording voor die sunelthein het geskied "deur die Heilige Gees." Dit is die lewewekkende en lewend. skeppende krag van God. In die rabbynse literatuur is hierdie betekenis van die woord egter onbekend; ${ }^{30}$ ) daar is dit die gees van profesie, die gees waardeur leiers en profete van Israel geinspireer is om te spreek, die gees wat in die skrywers van die Heilige Skrifte werksaam was. "Gees” is allegories ook op die gees van die Messias betrek ${ }^{31}$ ). Wel is dit vir die Joodse begrip aanvaarbaar dat God onmiddelbaar, skeppend kan ingryp, soos byvoorbeeld die ontvangenis en gebourte van Izak en Jakob; (vgl. Gen. 17:17; 18:11-14; 21:1-7; 25:21) om egter 'n maagdelike geboorte op die Messias te betrek, was (soos ons Ou Testamsntiese navraag reeds aangetoon het) iets ,absoluut nuuts”. „So bedeutet Matth. 1:18 dem Jüdischen Denken gegenüber ein absolut Neues"'32).

Sy geboorte sou plaasvind as mens uit mense ${ }^{33}$ ).

Die enigste enkele spoor van 'n maagdelike geboorte in die Jodendom, (en dan staan daar nog 'n groot vraagteken) meen D. Daube ${ }^{34}$ ) na te speur in die Haggadah vir die Paasfees op Deut. 26:5 v.v. Die Midrash het op tipies-rabbynse wyse 'n spesifieke betekenis aan elkeen van hierdie verse geheg; byvoorbeeld vers 7 verklaar die Midrash in verband met die betekenis van ,ons verdrukking": „Dit meen die verhouding van seksuele gemeenskap, soos dit geskrywe is (Ex. 2:25) ,En God het die kinders van Israel aangesien en God het hulle geken' ".

29) Die sunelthein is derhalwe deel van die Joodse bruilof mištê (Aramees mištîtâ). Vgl. Strack Billerbeck, a.a.O. II. S. 374 .

30) Strack-Billerbeck: a.a.O. I. S. 48.

31) Strack-Billerbeck: a.a.O. I. S. 48.

32) Strack-Billerbeck: a.a.O. I. S. 49.

33) Just. Mart. Dial. cum Trypho, aangehaal deur Str. Billerb. a.a. O. I.S. 49.

34) D. Daube: artikel in The Journal of Theological Studies," Vol. 1. 1949. P. 53 tot 57 . 
Die outeur van die Midrash het die woord ,ken" in seksuele sin opgevat en dit so uitgelê dat die moeder van Moses van God self ,ontvang" het ${ }^{35}$ ).

Daube konstateer duidelik dat dit slegs op hierdie plek in die Haggadah is, waar hierdie vir die Jood ",verwerplike fabel" oorgebly het . . ., we do not meet with it anywhere else."

Buitendien is dit ook moeilik om presies te verklaar wat die bedoeling van die Haggadah hier is: "The Haggadah is a piece of liturgy, and it is more difficult to expurgate liturgy than almost any other kind of literature" ${ }^{36}$ ).

Dat die „idee" van 'n maagdelike geboorte in die Jodedom aangewys kan word, is uit hierdie een onsekere grond wat Daube aanwys, nie genoegsaam oortuigend nie. Al sou Daube se teorie ook korrek wees dat die idee van 'n maagdelike gebooorte wel aangewys kan word, dan lyk dit nog heel onwaarskynlik dat hierdie maagdelike geboorte op die geboorte van die Messias betrekking kan hê. Die Joodse interpretasie van Jes. 7:14 het nie 'n maagdelike geboorte ingehou nie ${ }^{3 \tau}$ ).

Wanneer dr. Joseph Jacobs spreek oor die geboorte van die Messias verwys hy na die werk van prof. James Drummond: "The Jewish Messiah, a Critical History of the Messianic Idea among the Jews, from the rise of the Maccabees to the closing of the Talmud", en merk hieromtrent op: „There is not a scintilla of evidence in all this literature of anything corresponding to the Virgin Bith"38).

Matt. 1:19: „En Josef, haar man, omdat hy regverdig was en onwillig om haar openbaar te maak, het hom voorgeneem om in die geheim van haar te skei."

Ons kan vooraf reeds verwag, na die tekskritiese situasie van 1:16 dat hier waar daar sprake is van Josef as "haar man"

35) D. Daube: op. cit. p. 54-55. „Certainly, even if the legend came into existence after the New Testament, it would not be without interest, it woud still show that the notion of a virgin birth was not absolutely alien to the Jewish mind."

:s) D. Daube: op. cit. p. 55 .

3i) In verband met Jes. 7:14 vgl. voorafgaande O.T. deel, H. 1, a. Vgl. verder: Dr. Joseph Jacobs wat die Joodse standpunt stel in ..The Virgin Birth of Christ" deur James Orr, London, 1907, p. 288-291 en verklaar: "Throughout the wide extent of Jewish literature there is not a single passage which can bear the construction that the Messiah should be miraculously conceived ... (onderstreping van ons) ... This is sufficiently indicated by the absence of any suggestion in the very wide apocalyptic literature of the Jews which can be dated before the birth of Christ."

38) Dr. Joseph Jacobs: op. cit. p. 289. 
die teks weer spore van apologetiese arbeid sal vertoon. Dit is dan ook inderdaad die geval. Sy lees: „'n regverdige man" en laat die „haar man” weg $^{39}$ ).

Die Afrikaanse Bybelvertaling lui hier: „En Josef, haar man, omdat hy regverdig was en onwillig om haar openbaar te maak, het hom voorgeneem om in die geheim van haar te skei." Ons het hier weer dieselfde geladenheid in die terminologie en vir die korrekte sinsbepaling sal die Joodse agtergrond in die vertaling en eksegese moet meespreek. Wat betref die „Josef . . regverdig synde" (letterlik), wys prof. Geyse ${ }^{-10}$ ) daarop dat die Afrikaanse vertaling twee foute begaan het. Die participiale ,oun" is naamlik vertaal met 'n kousatief ${ }^{41}$ ) „omdat", terwyl dit hier niks meer wil wees nie as net relatief, dus te vertaal met ,wat" of hoogstens met die temporale „terwyl”: „En Josef, haar man, wat (of, terwyl) . .." Die tweede foutiewe vertaling is te wyte aan die direkte en nie by die Joodse agtergrond aangepaste oorsetting van dikaios. Die dikaios of sādîk is die aanduiding van 'n bepaalde godsdienstige stand onder die Jodedom ${ }^{42}$ ).

Josef het tot daardie stand behoort en so ook Sagaria en Elizabeth (Luk. 1:6). Die dikaioi was mense wat die wet geken het en dit stiptelik onderhou het. Prof. Geyser vertaal: ,Josef, wat 'n wets-onderhouer was ..." ${ }_{43}$ ). In hierdie sin het ook Strack-Billerbeck die dikaios kwalifiseer: „... vielmehr wird Joseph so als ein Mann charakterisiert, der das Gesetz zur Norm sienes Handelns gemacht hatte; und eben weil Joseph sich in seinem Gewissen an das Gesetz gebunden fühlte, will er aus der Schwangerschaft seiner Verlobten die gesetzlichen Folgen für sein weiteres Verhalten ihr gegenuber ziehn"*4).

39) „Deigmatisai" is die lesing van verskeie manuskripte. Die woord is baie skaars; kom voor in Col. 2:14. Deigmatismos on die Rosettasteen meen ,inspeksie"; sien Allen S. Matthew. p. 10. Die meer gewone woord paradeigmatisai word ingevoeg deur die Sirus Sinaiticus, C E K L al, word gebruik in Num. 25:4, Es. 4:17, Jer. 13:22, Es. 28:17, Dan 2:5, Ps. Sol. 2:14 en 5 keer in die LXX. Die tekskritiese kwessie insake die lesing paradeigmatisai in plaas van deigmatisai kan nie relevante betekenis-verandering meebring nie; albei het dieselfde betekenis: „om as voorbeeld te stel" ook in 'n slegte sin: „tot publieke skande stel." Vgl. J. H. Thayer: A Greek-Eng. Lex. of the N.T. bls. 126, 480. Vgl. krit. ap. Nestle: Novum Testamentum Greece 1949.

40) A. S. Geyser: Art. in Herv. Teol. Studies, 6de Jrg. 1949-1950, bls. 35.

41) Op die inkorrektheid van die kousatiewe "omdat" het ook Calvyn gewys, vgl. die reeds siteerde vertaling van "W. Pringle: Commentary on a Harmony of the Evangelists. deel I. bls. 94 .

12) Vgl. ook A. Schlatter: Der Evangelist Matthäus, S. 13. „In der Benennung der Frömmigkeit als ,Gerechtigkeit” ist Mat. mit den palästinischen Frommen völlig eins. Ihre religiöse Haltung war beständig durch die Teilung der Gemeinde in „Gerechte" und "Ungerechte”, und sâdîk, bestimmt."

43) A. S. Gevser: Aangehaalde artikel in H.T.S. 6de Jrg. 1949-1950, bls. 35.

44) Strack-Billerbeck: A.W. deel I, bls. 50. 

skei."

„En hy het hom voorgeneem om in die geheim van haar te

Ons stem in met die mening van prof. Geyser dat die Afrikaanse vertaling op voetspoor van die Statevertaling besware inhou ${ }^{45}$ ). „Lathra" beteken hier nie ,in die geheim" nie; so sou 'n dikaios trouens ook nie handel nie. Die regte betekenis van die woord is te soek in die samehang met deigmatisai, wat beteken om ,in opspraak te bring" of „bloot te stel" +6 ).

Die voorneme van Josef was dus om die verhouding te ontbind sonder om Maria in opspraak te bring, dit wil sê: in stilte. So word lathra ook vertaal deur die Leidsevertaling van die Nederl. B.G., Petrus Canisius en prof. Brouwer.

„Apoluein" is die palestynse formule vir die los-lating van die vrou, - geensins 'n egskeiding in die westerse sin van die woord nie. Volgens die Joodse wet is dit alleen die man wat 'n skeibrief ge. $\left.^{4 i}\right)$. Dit is ook volkome in ooreenstemming met die Joodse wet dat Josef as verloofde man genoem word "anēr autēs"'s).

Aangesien apoluein met die akkusatief van die voorwerp moeilik kan beteken „om te skei" en in aansluiting aan die Joodse woord-agtergrond betreffende die egskeiding, is dit beter om te vertaal „los te laat" of „te laat gaan”, (prof. Geyser), dus : „... en nie van plan was om haar in opspraak te bring nie, was hy voornemens om haar in stilte te laat gaan ${ }^{40}$ ). Luther vertaal: „Joseph aber war fromm und wollte sie nicht rugen" en voeg hieraan toe: „d.i. er wollte sie nicht zu Schanden machen vor den Leuten, als er wohl Macht hatte nach dem Gesetze. Und rühmt also St. Matthäus Josephs Frömmigkeit, dass er sich auch seines Rechten um Lieben willen verziehen hat. (vgl. Chr. Eberle: Luthers Evangelien - Auslegung aus seinem homiletischen und exegetischen Werken zusammengestellt. Uitg. Samuel Gottlieb Liesching, Stuttgart, 1857. S. 843).

45) A. S. Geyser: Aangehaalde artikel in H.T.S. bls. 35 en 36 .

46) A. Schlatter, A.W., bls. 14.

4i) Strack-Billerbeck: A.W. deel 2, bls. 393-394. Vgl. ook A. Schlatter: Der Evangelist Matthăus. S. 15. .Die Lösung der Ehe stand einzig im Ermessen des Mannes; den Richter bedurfte er zur Ausstellung des Scheidesbriefs nicht, und die Weise, wie er ihm in die Hand der Frau legte, stand bei ihm.

48) Strack-Billerbeck: A.W. deel 2, bls. 393-394. Vgl. ook prof. dr. J. A. C. van Leeuwen: Het Ev. van Matt., T. en U. bls. 71. „De verloving gold in Israel als begin van de sluiting van het huwelijk. Vandaar dat Maria in vs. 20 en 24 Jozefs vrouw kan genoemd worden. Vandaar ook, dat Joze, die rechtvaardig was, wettig recht meende te hebben van haal te scheiden."

49) A. S. Geyser: Aangehaalde artikel in H.T.S. bls. 36 . 
Matt. 1:20: „Maar terwyl hy dit in gedagte gehad het, verskyn daar 'n engel van die Here in 'n droom aan hom en sê: Josef, seun van Dawid, wees nie bevrees om Maria, jou vrou, by jou te neem nie, want wat in haar verwek is, is uit die Heilige Gees"50).

Mariam volgens Sinaiticus, C, D, en andere. S2 lees ,jou verloofde in plaas van ,jou vrou". Dus weer 'n apologetiese trek!

God gryp nou in: Deur 'n engel laat Hy Josef waarsku en inlig; dit gaan hier om die vervulling van die raad van God, om die verwesenliking van goddelike beloftes ${ }^{51}$ ); hieraan word Josef reeds herinner wanneer die engel hom aanspreek as „seun van Dawid".

„Idoe" kom dertig maal voor in Mattheus en „,kai idoe” agt en twintig maal ${ }^{52}$ ). Terwyl Josef as sādîk die toestand van sy verloofde en wat hom te doen staan oordink, kom die bode van God skielik en oorweldigend. Idoe wys op ,,die überraschende, jeder Berechnung entzogene Art des Voorgangs"s3). Die uitdrukking ,verskyn in 'n droom ... en sê..." kom in die Joodse literatuur meermale voor: Jer. Chagiga 78 d. e.a. plekke ${ }^{5 t}$ ).

Die feit dat die bode van God gestuur is, gee aan die opdrag wat Josef ontvang, sekerheid en verpligtende krag. Hierby neem ons in ag dat drome in die laat Jodedom 'n belangrike rol gespeel het ${ }^{55}$ ). Vir Josef is dit 'n openbaring van God wat as sodanig as opdrag uitgevoer moミt word.

Die Afrikaanse vertaling lui: „... om Maria, jou vrou, by jou te neem (nie) . . ." Ook al ses die reeds genoemde Nederlandse vertalings lees: „tot u te neem". Wat is die Joodse agtergrond? Paralabein is die "neem" van die vrou gedurende die bruilof uit haar staat van 'arûsâ tot nesûâ, dit wil sê tot die opname in die huis as eggenote, haknasâ. Josef, die sādîk hoef

50) A. Schlatter, a.a.O.S. 18, merk op: „Mündliche Tradition erzeugt Rythmik, die das Gedächtnis unterstützt. Die Gliederung der Sätze in annähernd gleich lange Stichen gehört zum Stil der Sentenzen und macht die griechischen Sätze den semitischen parallel."

51) Prof. dr. J. A. C. van Leeuwen: Het Ev. van Matth. in serie T. en U. bls. 70 .

52) W. C. Allen: The Gospel according to S. Matthew in die serie I.C.C., 3rd Ed. herdruk 1922. T. en T. Clark, Edinburgh, bls. 9.

53) A. Schlatter: a.a.O. S. 15.

${ }^{54)}$ A. Schlatter: a.a.O. S. 15.

$\left.{ }_{55}\right)$ Vgl. hieroor Strack-Billerbeck, a.a.O. Bnd. 1 S. 53-63. Verdere voorbeelde by A. Schlatter, a.a.O. S. 17. Daar was ook diegenes wat skepties gestaan het teenoor die mening as sou die droom ' $n$ goddelike openbaringsmiddel wees; hulle het die droom beskou as 'n stuk afval van die profesie (ein Abfall, schwaches Gegenstuck - Str.-Bill. I, bls. 57 en 58). In die Rabbynse literatuur kom dit egter ryklik voor as openbaringsmiddel. 
nie bevrees te wees om oor te gaan tot die haknasâ nie. Paralabein beteken dus eintlik: in jou huis op te neem, by jou te neem as eggenote. Hy kry van God die versekering dat Maria geen ontugvrou is nie; wat in haar verwek is, is uit (die) Heilige Gees ${ }^{56}$ ). Dat Maria hier ,jou vrou" genoem word, is soos ons reeds aangetoon het, volkome in ooreenstemming met die Joodse huwelik ${ }^{57}$ ).

Matt. 1:21: „En sy sal 'n seun baar, en jy moet hom Jesus noem, want dit is hy wat sy volk van hulle sondes sal verlos."

In hierdie vers voeg die twee siriese lesings $\mathrm{S}$. en $\mathrm{C}$. „,soi” in na "seun" soos Luk. 1:13. Dit is alleen 'n stilistiese toevoeging wat geen verandering aan die inhoud van die teks meebring nie.

Verder lees Ambrosius en ander „kalései”, en 1241 lees „kalesousie."

Die eerste gedeelte van die vers herinner sterk aan Jes. 7:14. Aangesien die engel die beroep van die Kind ken, ken hy ook sy geslag: „Die von Gott angeordnete Namengebung ist ein in. haltsvolles Zeichen für die Verbundenheit des Kindes mit Gott" ${ }^{58}$ ). God gee self die naam aan sy Seun: Redder, omdat dit $\mathrm{Hy}$ is wat sy volk sal red van hulle sonde. Calvyn sê dat Hy van die Vader 'n naam gekry het wat dadelik spreek oor die doel van sy koms, wat sy mag is en wat ons van Hom kan verwag $\left.{ }^{5 y}\right)$ ). Die naam Jesus is af te lei van die Hebreeuse verbum in die Hiphilvorm „Hoškia” (wat beteken, ,om te red') waarvan die Griekse vorm Iesous is. In hierdie verband vgl. ook Philo, De Mut. Nom. 1, 597: „Want hyself sal sy volk van hulle sondes red $\left.^{i v}\right)$. Vgl. ook Ps. 130:8.

In die Ou Testament is God die Verlosser van sy volk, vgl. ook Hosea 1:57. Wanneer Mattheus die verlossing van die volk Israel op Jesus as die Verlosser betrek, dan moet dit so verstaan word dat die Messias „,das Organ Gottes” by die heilsbewerking is ${ }^{\text {(1) }}$.

Nog voor Hy gebore is, word Israel genoem „laos autou”. "Wei dieser Jesus den königlichen Beruf zuteil, ist Israel, unabhängig vom Erfolg seines Wirkens, ob er verworfen wird oder ob ihm geglaubt wird, noch ehe er geboren ist, sein Volk;2).

56) Oor die dlaad' van (die) Heilige Gees het ons reeds in v. $18 \mathrm{~b}$ gehandel.

5i) Vgl ons eksegese van v. $18 \mathrm{a}$.

58) A. Sehlatter: Der Evangelist Matthäus, S. 19.

59) W. Pringle: John Calvin: Commentary on a Harm. of the Evangelists, p. 98.

6o) W. C. Allen: S. Matthew in serie I.C.C., p. 9.

61) Strack-Billerbeck: a.a.O. Bnd. I, S. 67-70.

62) A. Schlatter: Der Evangelist Matthäus. S. 19. 
(Ons onderstreep). Dit is die hama:tia ${ }^{63}$ ) wat die volk verderf; die volk is daarom verlore en het 'n redder nodig om hulle uit hierdie staat van verlorenheid te haal. Die herstelling kan plaasvind deur vergifnis van hierdie hamartia, deur versoening moontlik te maak. Met laos word hier die volk Israel verstaan, die kinders van Abraham (vgl. ook 1:1). Met 'n beroep op Rom. 11:17 voeg Calvyn $^{6 t}$ ) hieraan toe dat hierdie belofte van redding, nie lank hierna nie tot die heidendom gerig is, uitgebrei is tot almal deur die geloof tot die „een liggaam” (1 Kor. 12:20) behoort.

Die ,aanvang” en die „uitgang” van Jesus Christus word hier saamgestel in dieselfde orde: So as Hy deur sy kruisdood die vergifnis van sonde moontlik maak, so is Hy reeds by sy geboorte die Redder uit die sonde: sy geboorte en ons verlossing uit die hamartia hang ten nouste saam.

Matt. 1:22 en 23: „En dit het alles gebeur sodat die woord vervul sou word wat die Here deur die profeet gespreek het: Kyk die maagd sal swanger word en 'n seun baar, en hulle sal hom Emmanuel noem, dit is, as dit vertaal word: God met ons".

Verskeie Mss. voeg by vers 22 in: „Jesaja”, voor „profeet” byvoorbeeld vers 23 lees D en 'n paar ander „kalesouseis", (2de pers. enkelv.).

Dat dit hier gaan om die wonderbaarlike vervulling van die goddelike belofte, blyk nog meer uit die nadruklike versekering van die engel waarom dit alles so gebeur het: opdat die profetiese Godswoord in vervulling sou gaan (vgl. Jes. 7:14). Agas tot wie Jesaja hierdie woord gespreek het, het dit onmoontlik geag dat Jerusalem uit sy benardheid en benoudheid verlos kan word; hy wil selfs 'n teken, die sigbare waarmerk van die toesegging van God, nie vra nie. God wys dan self daardie teken aan as tasbare bewys van sy gedagte van vrede. Waarom sal hy dan tóg Juda en Jerusalem verlos? Ook dit het sy grond in die verordinering van die Seun tot Messias $^{65}$ ). Die teken van hierdie raad van vrede, is die wonderbaarlike ontvangs van hierdie Kind, wie die naam sal dra van Emmanuel.

63) Dit val buite ons bestek om hier nader in te gaan op die betekenis van hamartia. Die feit dat dit in die pluralis staan dui daarop dat hier nie 'n toestand bedoel word nie, maar die handelinge, (sondige dade), woorde, gedagtes van die mense wat hulle doel gemis het. - Vgl. J. H. Thayer: op. cit. p. 30. Vgl. ook die opmerking van A. Schlatter: a.a.O. S. 20. "Es beziecht also das Urteil "Sunde" nicht auf einem Zustand, sondern auf das Handeln des Menschen, nicht auf das, was dieser ist. sondern auf das was er tut.

64) W. Pringle: Commentary on a Harmony of the Evangelists by John Calvin, I, p. 99.

65) Prof. dr. J. A. C. van Leeuwen: Het Ev. van Matth. in T. en U. bls. 71 
Het ons gesien dat dit in vers 21 gegaan het om die roeping, werk, amp (Koning en Verlosser) van Jesus, sien ons hier weer dat naas sy werk, Mattheus die Woord stel. So skilder Matthèus ook deurgaans die werkende Jesus: naas sy (wonder-) werke staan sy woorde: „Denn das Werk bleibt stumm ohne das Wort, das den inneren Grund der Tat enthült, und das Wort fällt dahin ohne das Werk, in dem es seine wirksame Kraft offenbart" ${ }^{\text {"sco }}$ ). Hier waar vir die eie woord van Jesus nog geen ruimte is nie, tree die woord van die profeet in, welke woord gewigtig is omdat dit aandui dat in hierdie gebeurtenis die wil van God geskied.

Die inleidende formule (v. 22) wat 'n min of meer vaste vorm het, ,sodat die woord vervul sou word" dui daarop dat Mattheuus dit wat gebeur of gedoen word, onder die goddelike wil stel deurdat dit in ooreenstemming met 'n Skrifwoord geskied. Die formule van Mattheüs is nie slegs 'n verhaling van die Joodse nie, maar wel 'n parallelle uitdrukking; vergelyk die oudste Hebreeus, I Kon. 2:27: om die woord van die Here te vervul ${ }^{67}$ ).

In die Mattheusformule is die voorstelling dat die woord leeg bly solank dit nie verwerklik is nie; dit word vol wanneer dit geskied (gebeur), tot gebeurtenis en geskiedenis word. "Torhethen" word dikwels gebruik so as ook „dit is geskryf". Wanneer die woord geskryf word, is dit fikseer en vir alle geslagte tot outoriteit gemaak; dit sal onveranderlik deur alle tye bly staan. Dit is egter nie sonder betekenis nie dat die aandag ook ten alle tye op die gesproke-woord gerig bly, welke woord die geskrewe woord vooraf gaan. Die gawe van God aan die volk bestaan daarin dat sy Woord tot hulle kom, ook in gesproke vorm, (to rhyma).

Vers 23 is 'n kwotasie uit Jes. 7:14, volgens die LXX lesing, met die uitsondering van kaleseis van die $\mathbf{L X X}$ wat op hierdie konteks nie pas nie, verander is na kalesousin. In plaas van heksei (LXX A Q) word lympsetai gelees deur LXX $B^{65}$ ).

66) A. Schlatter: Der Evangelist Mathäus, S. 20-21.

67) Die formule ,sodat die woord vervul sou word" vind ons weer in Matt. $2: 15$ en $23,4: 14,8: 17,12: 17,13: 35,21: 4$, vgl. $26: 56$; ,toe is vervul wat gespreek is" sien 2:17 en 27:9. Vgl. ook A. Schlatter, Matthäus, S. 21 en W. C. Allen: S. Matthew, p. 9.

68) Vgl. W. C. Allen: S. Matthew, p. 10. 
Ons het in vooorafgaande gedeelte die vraag gestel waarom die LXX vertalers 'almâ met parthenis gaan vertaal het? (Die Hebreeuse 'almâ beteken immers 'n jong getroude vrou totdat sy haar eersgeborene gebaar het; in die woord 'almâ lê die begrip van maagdelikheid nie noodwendig opgesluit nie soos in betûlâ nie). Ons het na 'n antwoord op hierdie vraag gesoek en verklaar as enersyds uit die neiging om die bowe-natuurlike en wonderbare van die aangekondigde Kind en sy geboorte te beklemtoon; andersyds het ons aangetooon dat die profeet waarskynlik in sy gedagte 'n nawerking gehad het van oudOosterse verlosserverwagtingsvoorstellings. Wanneer Allen ${ }^{69}$ ) egter gewoon konstateer: ,There are signs that the view that Isaiah was using current mythological terms, and intended his hacalmá to carry with it the sense of supernational birth, is right'iy regaining ground," (ons onderstreep) wil ons meer versigtig hier byvoeg dat die gebruik van hierdie oud-Oosterse materiaal formeel en met voorbeeld gebruik is en nie materiëel en op direkte wyse uit die heidendom oorgeneem is nie. Ons het naamlik hier nie te doen met „etwas Naturhaftes im Sinne von Zeugung (und Geburt)" soos in die ,hieros gamos" nie ${ }^{70}$ ).

Waar Mattheus ons 'n nugtere vertelling aanbied, is die mitologiese verhale gewoonlik oorversadig met "sublimierte Biologie"'in).

69) W. C. Allen. S. Matthew. bls. 10 verwys na Jeremias, „Babylonisches im Neuen Testament,” bls. 47 en die werk van Gressmann: „Der Ursprung der Israelitisch-jüdischen Eschatologie."

io) Vgl. K. L. Schmidt: Art. „Die Jungfrau Geburt Jesu Christi”, in Theol. Blätter no. 12 jrg. 14, Des. 1935, bis. 290. Verder: Paul Feine: 'Der Apostel Paulus. C. Bertelsmann, Gütersloh, 1927, S. 509 verklaar: „Es ist zu verstehen dass in der religionsgeschichtlichen Untersuchungen gerade auch wieder neuesten Datums die Geburt Jesus durchaus in eine Linie mit den mystischen Vorstellungen von den antiken Königen, Weltherrschern oder Religionsstiftern als Gotteskindern gestellt wird. ohwohl in der christlichen Ueberlieferung legendäre zuge, wie sie von dem Zarathustraoder Buddhakind oder dem Götterkind der vierten Ekloge berichtet werden, vollig fehlen. Wer von aussen an diese Vorstellungen herantritt wird versucht sein, die ziemlich durchgangige Parallelität in den Vordergrund zu stellen. (Onderstreping van ons).

71) A. Schlatter: Matthâus. S. 22. „Bei der Deutung des Matthäus haben solche Erwägungen keinen Raum; denn von Reflexionen auf das, was jenseits des Judentums von Mythos und Religion vorhanden war, zeight sein Bericht nich die geringste Spur." Vgl. ook: K. L. Schmidt: "Die Jungfraüliche Geburt Jesu Christi” in „Theologische Blätter" No.: 12 , Jrg. 14, Des. 1935, S. 290. 
Hoe oud die verbinding van hierdie profesie met die geboorte van Jesus Christus is, weet ons nie ${ }^{i 2}$ ).

Ons weet ook nie hoe Jesus self Jesaja 7 gelees het nie. Duidelik is egter die reaksie teen hierdie interpretasie van Jes. 7:14; latere vertalers het byvoorbeeld parthenos geskrap en met neanis vervang ${ }^{i 3}$ ).

\section{Met ons (is) God:}

Immanuel is nie die ampsnaam van Jesus nie. Met hierdie naam is aan die gemeente gesê hoe God teenoor haar staan, „dass ihr mit der Gegenwart des Christus Gottes gnädige Gegenwart gegeben sei"' ${ }^{i 4}$ ).

Hier word aangedui op welke wyse dit moontlik is dat God met die mens omgang maak: in Christus. Calvyn sê dat die tyd van die "skaduwees" verby is en verwys na Kol. 2:9: „Want in Hom woon al die volheid van die Godheid liggaamlik." Deurdat Hy „Immanu-el” is, kan Hy ook Middelaar wees. Immanuel is gelyk aan , . . . God is geopenbaar in die vlees . . ." 1 Tim. 3:16 en Joh. 1:14: „En die Woord het vlees geword.” „Die eerste saak

i2) Vgl. hieroor A. Schlatter: Matthäus . bls. 22. Ons het reeds gesien dat Schlatter van mening is, en ons stem daarmee in, dat die Mattheusverhaal nie mities is nie. Schlatter voeg egter hieraan toe: "Nur bei der Auslegung des griechischen Jesaja hat die Erwägung Grund, ob der in Agypten lebenden Rabinne des dritten Jahthunderts, der hier parthenos einsetzte, einer Spekulation folgte, die den Mythos, etwa den aion oder Legenden über van Göttern erzeugte Könige mit der jesajanischen Verheissung kombinierte." In hierdie rigting soek ook Paul Feine na 'n oplossing. Der Apostel Paulus: bls. 48. „Wahrscheinlich ist in der Zeit und Umgebung des Uebersetzers die Vorstellung herrschend gewesen, die Mutter des Erlösers sei eine Jungfrau. Dann muss in der Zeit des Uebersetzers von Jesaja, der um $200 \mathrm{v}$. Chr. angesetzt wird in jüdisch hellenistischen Kreisen die Ueberlieferung von der Geburt des Erlöserkindes aus einer Jungfrau bereits eine so feste Stelle gehabt haben, dass dem Uebersetzer die Einsetzung der Jungfrau für den neutralen Begriff des Jungweibes bereits als selbstverständlich erscheinen konnte. Damit aber wird man zu der Voraussetzung geführt dass diese Anschauung schon eine gewisse Zeit hinter sich hat, die man im einzelnen nicht bestimmen kann, die aber doch in die alttestamentliche Zeit hineinreichen kann." Feine verwys in hierdie verband ook na $\mathbf{R}$. Kittel: Die Hellenistische Mysterienreligion, bls. 6 v.v. en E. Peterson: „Die Wunderbare Geburt des Heilandes", bls. 10.

i3) Vgl. Dr. Joseph Jacobs in „The Virgin Birth of Christ" deur James Orr, p. 288, 289. Ook: Calvyn in: Commentary on a Harmony of the Evangelists. Vertaal deur W. Pringle, p. 103-104. Paul Feine: Der Apostel Paulus, S. 481: „Haben die nachchristlichen Uebersetzer Aruila, Theodotion und Symmachus in den Streben nach besonderer Wörtlichkeit der Uebersetzung, für parthenos das neutrale neanis eigesetz, so darf angenommen werden, dass sie sich damit in Gegensatz zu dem inzwischen ausgebildeten christlichen Weissagungsbeweis haben stellen wollen, der in jenem parthenos eine wichtige Stütze für die evangelische Erzählung von der Jungfrauengeburt „Jesu" gefunden hatte."

it) A. Schlatter: Der Evangelist Matthăus, S. 23. 
wat ons in hierdie naam moet insien, is die goddelike majesteit van Christus om dan aan Hom die eerbied te gee wat die enige en Ewige God toekom" ${ }^{75}$ )

Matt. 1:24 en 25: „En tae Josef uit die slaap wakker word, het hy gedoen soos die engel van die Here hom beveel het en sy vrou by hom geneem; en hy het haar nie beken totdat sy haar eersgebore Seun gebaar het nie, en hy het Hom Jesus genoem."

Bywerking by die oorspronklike teks is met die eerste oogopslag duidelik. Natuurlik is die tēn gunaika autou in die gedrang: Sekere Mss. vervang dit met „Maria”, klaarblyklik om die indruk as sou Josef en Maria as man en vrou saamgeleef het, uit die weg te ruim. Die latynse $K$. laat die ,hy het haar nie beken nie totdat" weg, terwyl die Diatessaron, gevolg deur C, invoeg ,hy het rein saam met haar geleef." Verder voeg C.D. en ander lesings in "haar seun, die eersgeborene" (Vgl. Luk. 2:7).

Die formule "toe hy uit die slaap wakker word" behoort tot die Ou Testamentiese Hebreeuse en Palistynse spraakgebruik. (Vgl. Gen. 28:16 en Sag. 4:1). Die semitiese parallel verskil egter met die Mattheusformule in die sin dat die pronomen by ,hupnoe" vir die semitiese taalgevoel onontbeerlik is terwyl dit by Mattheus hier uitgelaat word ${ }^{i ø}$ ).

Oor paralabein het ons reeds gespreek by die eksegese van Matt. 1:20.

Die apologetiese latere toevoeging wat juis ten doel het om die verhaal van die maagdelike geboorte te stut, "nie baken nie" is in geslagtelike sin bedoel: „beken" "). Die „,hij bekende haar niet" van die Statevertaling asook die Lutherse vertaling word nog meer duidelik deur die Leidse- en nuwe N.B.G.-vertalinge gestel: „hij hield geen gemeenschap met haar" en „hij had geen gemeenschap met haar", onderskeidelik. Prof. Brouwer vertaal meer eufimisties: „hij leefde niet met haar als echtgenoot.” Die gebruik van die imperfectum wys dat die R.K. leerstuk van die durende maagdelikheid van Maria moeilik houdbaar kan wees ${ }^{i 8}$ ).

75) Calvyn: „Commentary on a Harmony ..." (vertaling (Pringle) p. $105,106$.

76) Vgl. ook ander taalkundige verskille by $\mathbf{A}$. Schlatter: Matthäus, p. 23 en 24.

ii) Vgl. J. H. Thayer: op. crit. p. 117. „.. . a Hebraistic euphemism, found also in Grk. writ. fr. the Alexandrian age down, . . . is used of the carnal connection of male and female."

78) Vgl. o.a. hieromtrent: A. Schlatter, a.a. O. S. 24. W. C. Allen, St. Matthew, p. 10. 
Calvyn (1) verwyt Helvidius ten opsigte van hierdie „en hy het haar nie beken nie", omdat hy hieruit afgelei het dat Maria slegs tot haar eersgeborene 'n maagd gebly het en dat sy daarna ander kinders by haar man gehad het. Maar hy het dit ook teen Hieronymus omdat hy weer die gedagte van 'n durende maagdelikheid hier ingelees het. Nee, voeg Calvyn ${ }^{-0}$ ) hieraan toe, ons moet daarmee tevrede wees dat geen regverdige en goed gefundeerde konklusies uit hierdie woord getrek kan word, wat betref die gebeure na die gebourte van Christus nie. Dat Hy eersgeborene genoem word, beteken alleen dat Hy uit 'n maagd gebore is. Josef het haar nie beken nie totdat sy haar eersgeborene seun gebaar het nie; dus 'n beperkte tyd: vergelyk "totdat". Wat daarna (nadat) plaasgevind het, word ons hier nie vertel nie. Wie hier verdere vrae stel, sê Calvyn, doen dit uit nuuskierigheid en 'n buitengewone liefde vir disputasies ${ }^{50}$ ). Luther, wat hier vertaal „Und erkannte sie nicht, bis sie ihren ernsten Sohn gebär", meen dat ons hier te doen het met 'rs spreekwyse van die Skrif (soos in Gən. 8:7) waaruit ons nie kan aflei dat Josef sy vrou wel na die geboorte beken het nie ${ }^{\text {11 }}$ ). Slegs dit is duidelik: Tot die geboorte van die Kind van Maria, wat volgens die bevel van die engel, deur Josef „Jesus” genoem word, het Josef hom van huweliksgemeenskap met haar onthou.

Matt. 13:55 (Vgl. ook Mark. 6:3): „Is Hy nie die seun van die timmerman nie. Is die naam van sy moeder nie Maria en die van sy broers Jacobus en Joses en Simon en Judas nie?"

Ons sal hoofsaaklik handel oor die onderstreepte gedeelte: Sekere Mss voeg by: „van Josef”.

Waar Markus 6:3 lees: „Is Hy nie die timmerman, die seun van Maria” (ens.), voeg Mattheus in: „die seun van die timmerman" in plaas van ,die timmerman".

Hierdie terminologie moet teen sy semitiese agtergrond verstaan word. Die uitdrukking ,seun van ..." dui 'n wesenlike identiteit aan. Beide uitsprake, die van Markus en Mattheus, wil een en dieselfde sê: die seun van die timmerman is die Oosterse skeldwoord "seun van 'n hond", word nie bedoel om

79) Sien: W. Pringle: Commentary on a Harmony of the Evangelists by John Calvin, I, p. 107.

80) A.W. bls. 107.

81) Chr. Eberle: Luthers Evangelien-Auslegung aus seinem homiletischen und exegetischen Werken zusammengestellt. Samuel Gottlieb Liesching, Stuttgart, 1857. S. 483. "Soll nicht verstanden werden, dass Joseph Mariam hernacht erkannt habe. sondern es ist ein Weise zu reden in der Schrift als 1 Mos. 8. 7: der Rab' sei nicht wiederkommen. bis die Erde trocknete, will die Schrift nicht, dass der Rabe hernacht kommen sei, also auch hie volgt nicht, dass Joseph Mariam hernacht erkannt habe." 
soseer die vader van die betrokke persoon te kenskets nie, maar wel die betrokkene self. Wat iemand is, word bepaal deur sy vader te noem. Wanneer Petrus Jesus bely as „Seun van die lewende God" bedoel hy: Jesus is God. (Vergelyk dr. A. van Selms: Licht uit Licht, Uitg. Ploegsma, Amsterdam, 1948, bls. 66 en 67). In plaas van ,die seun van Maria” gebruik Mattheus die parafrase "word sy moeder nie genoem Maria nie?"

Mattheus kon natuurlik ook gewoonweg „die seun van Maria" vervang het met en Maria, maar dit is te betwyfel of Matheus, terwyl hy geen beswaar gehad het teen die uitdrukking ,seun van die timmerman" = "seun van Josef" nie, ook wel sou kon skryf: „seun van Josef (of: die timmerman) en Maria." Vir die outeur was Jesus legaal die seun van Josef en "fisies" die seun van Maria. Hy sou waarskynlik 'n uitdrukking wat Jesus sou aandui as die seun van Josef in dieselfde sin as seun van Maria, nie gebruik het nie.

Om hierdie rede kom in die plek van ,die seun van Maria" die omskrywing: word sy moeder nie Maria genoem nie of: „Is die naam van sy moeder nie Maria nie?"

Hierdie vers kan dus nie gebruik word as 'n bewysplek om aan te toon dat Markus "geglo" het dat Jesus die natuurlike Seun van Josef en Maria was nie ${ }^{83}$ ).

Die feit dat Jesus tot ' $n$ ambagsfamilie ${ }^{84}$ ) behoort het, was vir sy werksaamheid nie sonder betekenis nie. 'n Timmerman kon in Nazareth moeilik 'n lewensbestaan maak. Die naaste arbeidsgeleentheid was in Sefforis, die hoofstad van Galilea wat 4 v.C. deur die Romeine afgebrand is en gedurende die jeugjare van Christus weer opgebou is ${ }^{85}$ ).

Konklusies ten opsigte van die Evangelie volgens Mattheus:

(1) Mens staan enigsins verbaas om te sien hoe ywerig die vroeë christelike oorskrywers was in hulle apologetiese omskrywinge en aanvullinge ten opsigte van die maagdelike geboorte

82) Na die moontlikheid dat Josef reeds oorlede was, verwys W. C. Allen: St. Matthew, bls. 156. "Since parentage in Palestine was always reckoned (and expressed) from the father, it may be argued with much probability that MK's huios tês Marias implies either the death of Joseph, or, more naturally, an allusion to the supernatural circumstances of the birth of Jesus." Sien daaromtrent ook Alfred Plummer: S. Matthew, bls. 199.

83) Vgl. ook W. C. Allen: St. Matthew, bls 156 . "The verse is eintirely misquoted when it is used as an argument that $\mathbf{S}$. Mark himself believed Jesus to be the natural Son of Joseph and Mary. He may have so believed, but no proof of such belief can be found in this passage.

84) Ons het hier gehandel oor die „vaderskap" van Josef volgens Mattheus en gaan hier nie in op die betekenis van "sy broers" (,sy susters") nie. Onder andere wys Calvyn daarop dat in die Hebreeuse idioom ook die gedagte van familie in breër sin opgesluit lê en nie noodwendig bloedbroer en -suster nie. Vgl. A.W. 2 bls. 215.

sã) Vgl. A. Schlatter: Der Evangelist Matthäus, bls. 455. 
van Jesus Christus, hier ten opsigte van die geboorteverhaal volgens Matt. 1:18-25 maar veral die genealogiese gegewe materiaal in Matt. 1:16. Gesien die woord-agtergrond van byvoorbeeld "anēr autēs" en "gunē autou" ensovooorts, is baie van hierdie apostoliese arbeid eintlik onnodig gewees; gesien egter die stroom van Joodse laster ten opsigte van herkoms van Jesus kan mens die oorsprong van die apologetiese houding verstaan; kan mens ook verstaan waarom die verhaal van die maagdelike geboorte (ook die genealogie) in die evangelie volgens Mattheus (en Lukas) opgeneem is.

(2) In die evangelie volgens Mattheus word die maagdelike geboorte nie verwerp nie, inteendeel, die hele perikoop 1:18-25 in sy geheel veronderstel hierdie wonderbaarlike geboorte; hierdie geboorte is ook nie 'n miskenning of teëspraak teen die genealogie nie en Josef is nie 'n ,vermeende" vader nie.

Nog minder is Matt. 13:55 teen die maagdelike geboorte bedoel. Terwyl hy geen beswaar teen hierdie laasgenooemde uitdrukking het nie, waak hy teen die misverstand wat moontlik kan ontstaan as sou Jesus op dieselfde wyse ,seun van die timmerman = Josef" wees, as wat Hy seun van Maria is. Daarom praat hy nie in dieselfde asem van byvoorbeeld seun van die timmerman en Maria nie maar omskryf hy sorgvuldig sy bedoeling.

Waarom nie? Omdat Josef wel vader van Jesus was, maar in legale sin. Egennesen (Grieks) is dieselfde as holît (Hebreeus), wat beteken „verwek” in eintlike sin. (Dit kan ook in oneintlike sin gebruik word in legale betekenis). Wat ook die Joodse interpretasie van Jes. 7:14 was, wat ookal die bedoeling van die LXX vertalers was, Mattheus vind en sien hier die geskikte materiaal waarmee die wonder van hierdie te-gebore-synde-Kind en sy geboorte beskryf kan word en wel as uit die parthenos, maagd. Mattheus toon aan dat Jesus deur die vervulling van hierdie profetiese woord die Immanuel is; dat Hy ook deur die ,vervulling' van 'n profetiese woord die Ou Testamentiese verwagte Messias is via sy Dawidseunskap, dus ook via Josef (uit die geslag van Dawid) in legale sin. Al sou die genealogie ook geëindig het met: ,en Josef het Jesus verwek”, sou dit onses insiens nog niks teen die maagdelike geboorte gesê het nie omdat Mattheus dit nie in fisies-biologiese sin bedoel het nie - dan sou hy 1:18-25 moes skrap - maar wel in legale sin.

Mattheus wou die fisiese nie uitsluit en in docetisme verval nie - die fisiese realiteit voer hy terug na die geboorte uit die 
maagd Maria. Ook die legaliteit van sy Dawidseunskap kan nie anders nie as via Josef( uit die geslag van Dawid) bewys word nie.

(3) Uitdrukkings soos „haar man” en „sy vrou” tydens die verlowing, ,sunelthein", deigmatisai, lathra apolusai, paralabein ensovoorts kan alleen verstaan word teen die Joodse agtergrond insake hulle verlowings-, huweliks- en egskeidingspraktyke. Onduidelike vertaalwerk is die resultaat wanneer hierdie feit uit die oog verloor word.

(4) Reeds by die aankondiging van sy geboorte word Jesus geplaas midde sy volk, (Immanuel) as Redder deur vergifnis van sonde.

(5) „Hy het haar nie beken nie”, wat deur die latynse $K$ en siriese $\mathrm{S}$ weggelaat word, verklaar nog niks aangaande enige gebeure na sy geboorte nie (vgl. Luther en Calvyn o.a.); kan daarom nóg vir nóg teen die Roomskatolieke leerstuk van die durende maagdelikheid van Maria gebruik word. Die imperfekum wys teen die geldigheid van laasgenoemde leerstuk. Die uitdrukking self is in geslagtelike sin bedoel en dui op egtelike gemeenskap.

(6) Belangrik: Slotkonklusie:

Hoewel die maagdelike geboorte van Jesus Christus deur Mattheus erken word en ywerig deur die apologetiese aanvullinge en omskrywinge verdedig word, kan ons nie sê dat dit in die res van Mattheus-evangelie ' $n$ belangrike rol speel nie. $\mathbf{N a}$ die geboorte-verhaal sien ons die onderlinge erkenning daarvan in 13:55. Jesus self spreek nooit daarvan nie en in die evangelie volgens Mattheus word dit ook nie weer gebruik nie. 